\section{LA FLOR DE LIS}

MARÍA CABALLERO

Universidad de Sevilla cuando fuimos a vivir allí. No sé exactamente qué sentí, pero recuerdo que me impresionó el sol, la luz, la gente ${ }^{3}$.

La mayoría de los críticos -por ejemplo Pino-Ojeda en su excelente artículo ${ }^{4}$ - hablan de Mariana como la protagonista del libro. A simple vista, qué duda cabe... es ella la voz que va desenvolviendo el paso de niña a mujer al modo del bildungsroman. Su estirpe noble, europea, el contexto de la segunda guerra mundial que moviliza al padre y obliga a las mujeres de la familia a desplazarse al sur y definitivamente viajar a México - «Sofía y yo no sabíamos que mamá era mexicana» ${ }^{5}$ -dirá asombrada ante el sesgo que toma su vida-. Por fin, el doble proceso de maduración existencial e identitaria, como persona y miembro de una comunidad, la de ese país del Nuevo Mundo. Todo eso está ahí y es el hilo conductor de La Flor de Lis. Pero el auténtico eje escondido es Luz, la madre de Mariana. Ella es la verdadera protagonista ${ }^{6}$, porque su hija gira en torno a ese faro, no tan luminoso, errático en ocasiones, oteando su misterio, reclamando su atención, sintiéndose eternamente excluida del paraíso, del útero materno para el que no hay retorno. Es la mariposa, la libélula siempre alrededor... pero es humana; por ello la interpela una y otra vez. Tienen mucha razón quienes -como Bados-Ciria- «analizan el tropo del apóstrofe como estrategia retórica que se despliega a lo largo de la obra posibilitando un discurso ciertamente original y propicio para una subjetividad femenina narradora» ${ }^{7}$. La madre es la destinataria, una madre siempre ausente ante quien la niña se siente invisible, lo que la incita a interpelarla. No hay más que escoger algunos párrafos al azar:
María Caballero

Wangüemert

Es Catedrática de Literatura Hispanoamericana en la Universidad de Sevilla. Su actividad docente en el Departamento de Filologías Integradas (Literatura Hispanoamericana) se compagina con la investigación. Ha publicado más de ochenta artículos, además de libros sobre autores argentinos -Borges, Mújica Láinez, Sarmiento- y puertorriqueños como Hostos y Marqués. Sus actuales investigaciones se centran en la narrativa -memorias, literatura femenina-, el cine y la teoría literaria. Ha sido profesor invitado en Francia, Alemania y San Juan de Puerto Rico.

1

Elena Poniatowska, La Flor de Lis, Madrid, Alianza Tres/Era, 1988 , p. 148. Citaré en el texto por esta edición.

2

Cf. Marta Paley de Francescato, «Convergencias en La flor de lis», Hispamérica, 62 (1992), pp. 127-132

3

Elena Poniatowska, "La verdad más íntima», en Reina Roffé, Conversaciones americanas, Madrid, Páginas de Espuma, 2001, p. 139.

4

Cf. Walescka Pino-Ojeda, «De agua y de ausencia: el sujeto autobiográfico femenino en La Flor de Lis de Elena Poniatowska», Estudios Filológicos, 39 (2004), pp. 203-220. Es el estudio más inteligente y completo que conozco sobre este texto. Poniatowska, La flor de Lis, p. 36.

6

$Y$ en eso tiene precedentes en la literatura mexicana, como recuerda en una conversación: «O los personajes de Nellie Campobello, a quien siempre se olvida, el personaje es su madre, tanto en Cartucho, como en Las manos de mamá, y las mujeres tienen mucha tendencia a reivindicar a las mujeres". Rocío Oviedo Pérez de Tudela, «Palabra y tierra: entrevista a Elena Poniatowska», Anales de Literatura Hispanoamericana, 30 (2001), p. 357.

7

Concepción Bados-Ciria, "Tecnologías autobiográficas en las narrativas personales de las escritoras hispanas», La Ventana 13 (2001), p. 269.

La Flor de Lis

MARÍA CABALLERO 


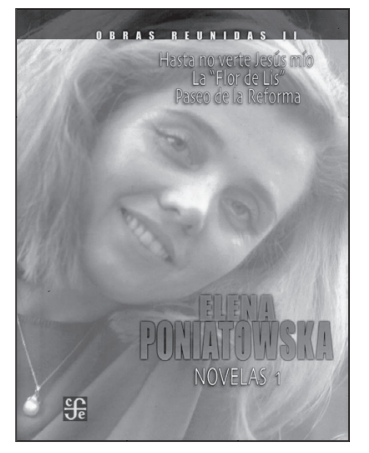

8 Poniatowska, La flor de Lis, p. 248.

9

Bados-Ciria, op. cit., p. 272.

10

Poniatowska, La flor de Lis, pp. 115-118.

11

Ibid., p. 34.

12

Ibid., p. 268.

13

Ibid., p. 47.

14

Ibid., p. 48.

15

Ibid., pp. 32-33.

16

Ibid., p. 248.

17

Ibid., pp. 32-33,

18

Ibid., p. 249

19

Ibid., p. 16.

20

Ibid., p. 45.

21

Ibid., p. 26.

22

Ibid., p. 29.

23

Ibid., p. 11.
Mamá, mírame, estoy aquí, mamá, soy tu hija, mamá mírame con tus ojos castaños, mamá no te vayas, cómo te detengo, no puedo asirte, mamá, dime que me oyes, no me oyes ¿verdad? ¿A quién escuchas dentro de ti con esa mirada ausente? ¿Quién te habita? ¿por qué no soy yo la que te importo??

La madre como objeto de deseo, el texto como declaración amorosa «de Poniatowska hacia su madre, ausente en su infancia»-dice Bados-Ciria9- y habría que matizar esa afirmación: ¿Mariana es Poniatowska, o se trata más bien de un ser ficticio tras el que se escudan reminiscencias autobiográficas, como es habitual en la autoficción? Lo veremos en el último epígrafe. Pero sea quien sea, la relación textual entre madre e hija es obsesiva:

No es que la extrañe, es que la traigo adentro. Hablo con ella todo el tiempo, hablo con ella en la lengua del sueño (...). No es que la extrañe, es más que eso. Corro tras de ella, de su día en México (...). la sigo obsesivamente (...). No es que la extrañe es que la vivo (...). Estoy segura de que nos sigue, vestida de luz y sombra (...). Todo el tiempo pienso en ella ${ }^{10}$.

¿Excesos sentimentales propios de la lejanía carcelaria del internado norteamericano a que pertenece este monólogo de la adolescente? En absoluto, más bien el distintivo habitual desde los nueve años en que «descubro a mamá»11. "Qué joven es mi madre, qué joven. Sus mejillas tienen la tersura de la infancia» ${ }^{12}$... «Oye, qué bonita es tu mamá» ${ }^{13}$... Una mamá dulce, inalcanzable y delgada, "que permanece siempre fuera de mi alcance» ${ }^{14}$, con una ausencia sólo suya... Una ausencia provocativa, desgarradora para quien la reclama a gritos: «oh, mamá, déjame asirte! (...) estira el cuello hacia el mar, le jalo el vestido, voltea a verme sin mirarme. ¡Dios mío, dile que me vea! (...) Aquí estoy, mírame» ${ }^{15}$... Una niña perdida en un barco que viaja a América en busca de paz y libertad, inexistentes en la vieja Europa, se agarra a ella como a tabla de salvación. Años después, la adolescente mantendrá la misma súplica: «¡Mamá, óyeme mamá ‘a dónde vas? Mamá»16. En ambos casos, la idealizada descripción de la madre es muy semejante:

Esa mujer allá en la punta es mi mamá; el descubrimiento es tan deslumbrante como la superficie lechosa del mar. Es mi mamá. $\mathrm{O}$ es una garza. $\mathrm{O}$ un pensamiento salobre. $\mathrm{O}$ un vaho del agua. $\mathrm{O}$ un pañuelo de adiós al viento. Es mi mamá, sí, pero el agua de sal me impide fijarla, se disuelve, ondea, vuelve a alejarse (...) El viento también sostiene sus cabellos en lo alto; el viento ciñe su vestido alrededor de su cuerpo ${ }^{17}$.

La atisbo por el corredor, más bien, es un paño de su vestido flotante, da la vuelta con ella y se escapa, la sigue como su sombra (...) su vestido es el puro viento, camina, su vestido danza en torno a sus piernas, adivino sus pálpitos bajo la tela que no la protege...18

La referencia a la garza la acerca a Darío y los modernistas, como ha notado PinoOjea, pero su imagen no es de este mundo, el misterio la aureola, a pesar de la incipiente sensualidad que debe mucho a la técnica de paños mojados, propia de las esculturas griegas, con que la narradora la describe en este último párrafo.

Tal vez ya sea hora de preguntarse ¿cómo es Luz? Dulzura, abandono, nostalgia, ausencia... pero sobre todo agua, aire, helechos, transparencia... cuatro semas que la definen. Hay mucha tradición literaria detrás: bella y muy blanca «su piel de leche blanquísima» -como las mujeres petrarquistas, románticas, prerrafaelitas...- «su rumor de bosque»... «el pelo que cae como una rama de árbol» (...), «oh mi mamá de flores» ${ }^{19}$, ya desde la primera descripción aparece fundida con la naturaleza, algo que nunca desaparecerá. «En el movimiento de su falda hay la transparencia de los helechos» ${ }^{20} \ldots$ «la envuelve su soledad verde esperanza; la nimba el verdor de los helechos. Ni cuenta se da del misterio que representa» ${ }^{21}$. Esa aura de misterio explica que, aún ligada a la tierra, al mundo vegetal, sea sin embargo etérea... «siempre hay algo que parece estarla esperando en otra parte y ella permanece hasta que viene el aviso y emprende el vuelo sobre las alas de su impermeable azul y blanco, aéreo, eléctrico, que la lleva suspendida por los aires»22. El azul-cielo de los románticos y modernistas, de Mallarmé, con un toque exótico de modernidad, como nuevo Altazor, aunque $\sin$ sus secuelas. A una mujer así le corresponden gasas, vestidos rumorosos y transparentes, propios de la exquisitez decadentista de hace más de un siglo. No en vano, parece... «salir de un ropero antiguo (...), de la Biblioteca Rosa de la condesa de Ségur» ${ }^{23}$.

Paradójicamente quizá el sema de la transparencia sea el único que le permita enraizarse, fundir tradición literaria y europeísmo con su país, México, «la región más transparente del aire» -¿quién no ha leído a Alfonso Reyes?-. El problema es que esa región y esa ciudad mítica quedan hoy mucho más cerca 
del mundo literario de Carlos Fuentes, contaminadas y recelosas frente a las extranjeras, afrancesadas o güeritas.

Moderna -fuma-, elegante "cada día con un vestido diferente, una bolsa diferente, unos ojos diferentes. Los vestidos son de Schiaparelli y son divinos, dirán di-vi-nos» ${ }^{24}$. «Lleva puesto el sombrero de paja con el listón negro, el del ramo de lilas, el del velito de tul, el anaranjado, la toca de terciopelo vino, el bonete de mink, la gorra vasca, el fieltro de viaje (...). J'ai une tête à chapeaux, afirma mamá y es verdad $»^{25}$. La enumeración caótica, con su golpeteo de imágenes visuales, pone ante los ojos del lector un modelo social, una mujer de mundo progresivamente incardinada en el México posrevolucionario, pero siempre inasible. Y siempre en la óptica de Mariana: «Yo era una niña enamorada como loca (...), el sólo verla justificaba todas mis horas de esperanza» ${ }^{26}$.

La narradora adulta es consciente de ello: «Luz ejerce sobre mí una fascinación especial. Me hechiza»-diráa ${ }^{7}$-. Y lo considerará un fatum, asumido tras la indagación vital de la adolescencia. Una búsqueda de valores muy ligada a la identidad y en la que tendrá parte importante su encuentro con la religión de la mano de un personaje ambiguo, el padre Teufel. Un personaje por otros motivos también fascinante, por el que la joven experimentará una irresistible atracción identificándolo con lo más sagrado, el propio Hijo de Dios, enviado para iluminar, ser la alternativa a una Luz demasiado etérea y visionaria para convertirse en modelo. Mariana busca seguridad y cree encontrarlo en el sustituto al padre biológico: «sabré por fin cómo debe ser la vida, cómo querer, cómo ayudar. El padre ha venido al mundo a guiarnos, a rescatarnos» ${ }^{28}$. Para al fin descubrir sus limitaciones $y$, descorazonada, volver a la madre... de un modo radical y sin condiciones:

Me meto en su cama; volver a estar dentro de ella como ella dentro de su cama; su cama es su vientre y toda esa blancura lechosa proviene de sus pechos (...). Nunca voy a poder irme, mamá, nunca agarraré camino, atada a ti (...) estoy parasitada de ti, mamá, almacenada para siempre, mamá, transminándote, síntesis de todos tus esquemas ${ }^{29}$.

No podía ser de otra manera si, como dijo Casilda -su mejor amiga-, "para Mariana, amar es convertirse en la persona amada» ${ }^{30}$. Pero la narradora sabe que ese mundo de tradiciones en el que se educó está abocado a la soledad y la tristeza; herencia de mujeres-invernadero que se autofagocitan en un estéril juego de espejos. Por eso, la Flor de Lis se cierra con la misma interrogación de siempre: «mamá, la tristeza que siento, ¿ésa dónde la pongo? ¿Dónde mamá?»31.

\section{UNAS MUJERES «PECULIARES»}

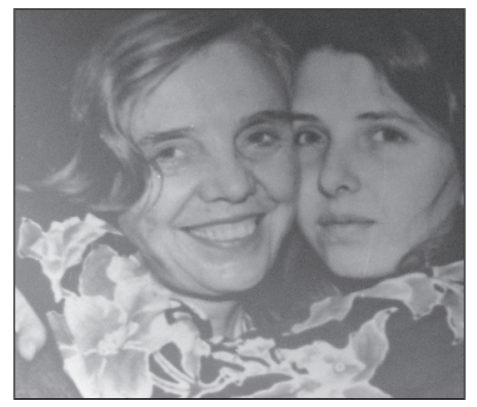

«Para mujeres, mi mamá: Luz. O mi abuela. O de perdida tía Francisca o tía Esperanza que podría cargar Catedral sobre sus hombros» ${ }^{32}$.

Resulta claro el protagonismo materno dentro del matriarcado que gobierna la vida de Mariana. No obstante, la abuela, quien simboliza mejor, dentro de la alta burguesía, el hibridismo cultural. Su afrancesamiento no le impide pasear con sus nietas los domingos por el centro: la casa de los Azulejos, la Profesa y el Zócalo, cuyo recuerdo provoca en la narradora los fragmentos más líricos y entrañables:

Amo esta plaza, es mía, es más mía que mi casa, me importa más que mi casa, preferiría perder mi casa. Quisiera bañarla toda entera a grandes cubetadas de agua y escobazos, restregarla con una escobilla y jabón, sacarle espuma, como a un patio viejo, hincarme sobre sus baldosas a puro talle y talle y cantarle a voz en cuello ${ }^{33}$.

El amor de la abuela por el D.F. se prolonga en... «su mirada reflexiva sobre el campo, la inmensidad en sus ojos y cómo, a la hora del crepúsculo, en la penumbra del coche de alquiler, respiraba hondamente el fluir de los arroyos subterráneos» ${ }^{34}$. Los recorridos en coche por las carreteras que transparentan su capacidad de admirar el paisaje desde miradores y cunetas. Es... «su afán por tragarse el paisaje» ${ }^{35}$ lo que cautiva a Mariana, su fascinación por los productos de la tierra como nueva cronista de Indias:

Compraba lo que venden al borde del camino: el haz de nardos, el montón de claveles, los cempazúchitl, las nueces; manzanas, canastitas de tejocotes, dulces de leche, piedras en el camino a Querétaro, naranjas y jícamas a medida que íbamos llegando a la zona caliente ${ }^{36}$.

La melancolía -valor obligado de todo relato autobiográfico- hace su aparición con el declinar de la mamá grande:
24 Ibid., p. 43.

25

lbid., p. 86.

26

lbid., p. 55.

27

Ibid., p. 266

28

Ibid., p. 197

29

Ibid., p. 291.

30

Ibid., p. 251.

31

Ibid., p. 324

32

lbid., p. 162

33

lbid., pp. 61-62

34

lbid., pp. 21-22

35

Ibid., p. 219.

36

lbid., p. 218. 


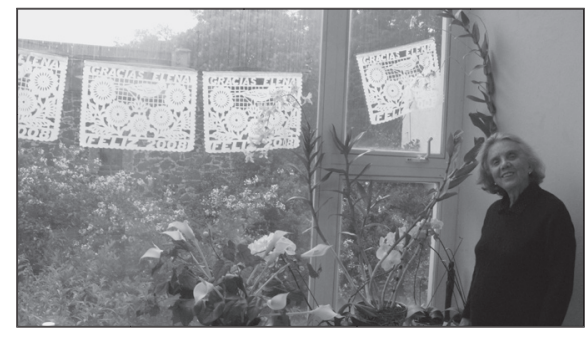

También mi abuela se ha entristecido. Pasa de un jardín al otro, su bastón en la mano, y ya no ríe a todas luces como reía antes, ni se interesa, como antes. Quiero fijarla, Dios que no sea demasiado tarde, obligarla, abuela, aquí estoy, mamá grande, soy yo, abuela tu me quieres, por si no lo recuerdas tu me quieres, tengo terror a esta ausencia que la va poseyendo, salto, 37 Ibid., p. 133

38

Ibid., pp. 226-227.

39

Ibid., p. 133.

40

Ibid., p. 102.

41

Ibid., p. 260.

42

Ibid., p. 131.

43

lbid., p. 138

44

lbid., p. 133.

45

lbid., p. 66.

46

lbid., p. 65.

47

lbid., p. 67.

48

Ibid., p. 69.

49

ld.

50

Ibid., p. 12.

51

lbid., p. 55.
La Flor de Lis

MARÍA CABALLERO manoteo frente a ella, veme aquí frente a ti, crecida y nueva, no me falles, no te duermas ${ }^{37}$.

Esa hibridez, esa doble vertiente enriquecedora, deberá pasar a la nieta puenteando la generación de las hijas, mucho más afrancesadas y románticas:

Las dos, Luz y Francisca, delgadas, etéreas, los músculos esquivos bajo las sedas entran haciendo el mismo gesto: se ponen unos guantes largos cuyos dedos enfundan ayudándose una mano con la otra (...). Caminan tan levemente que casi no pisan el suelo (...) su tiempo dichoso de mujeres bellas, su tiempo triste de mujeres que caminan con sus vestidos flotantes y sus vagas muselinas y sus cuellos delgadísimos y estirados como instrumentos de música....

Tía Francis fascina. Sus menús también. Al pan capeado en huevo que sirve con miel de maple le pone: Poor Knights of Windsor. Al espinazo con verdolagas que a Inocencia le sale del cielo: Cassoulet de L'Empereur Moctezuma $a^{39}$.

De las hermanas de Luz, Francis es a la que más páginas dedica la narradora. Exquisita en su ceremonia de té, flexible, inesperada y peligrosa en sus actitudes gatunas, inquietante para la protagonista: «hay un peligro en la tía Francisca y un reto en sus exigencias: Atrévete, atrévete, pero ¿a qué? Las expectativas familiares en cuanto a nosotras nunca quedan claras» ${ }^{40}$. Tiene su vertiente de independencia retadora frente al padre Teufel, por ejemplo, pero al cabo acaba subsumida por el grupo, una más junto a Luz y Esperanza. Son mujeres que la protagonista visualiza como transposición de su propia historia: «las imagino sobre la cubierta del barco, tal y como vinieron a México vestidas de blanco (...), en las fotografías del álbum de cuir de Russie le dan la cara al viento y se ven dichosas como hoy» ${ }^{41}$. Critican y ríen como una forma de autoafirmación.

Mariana y Sofía, su hermana, están concebidas como haz y envés de una misma moneda. Desde pequeñas son opuestas: Sofía es mañosa y rebelde, posesiva y todopodero- sa, independiente y retadora. Siempre supo qué hacer, «se quiere como ella es» ${ }^{42}$. Por el contrario, Mariana, que siente admiración por ella, se caracteriza por su deseo de agradar, por su soñar despierta, por la costumbre de diferir las decisiones, heredada de su padre «nadie sabe que sueño y jamás actúo» -monologará43-. Unidas en la infancia por la complicidad de la risa, se distancian en la adolescencia: la protagonista es más compleja, los genes maternos le lastran con un leve matiz de tristeza, soledad y melancolía que la soltura y el rechazo de las tradiciones de la hermana desconoce.

Bien pensado, el auténtico contrapunto femenino parte de los de abajo, y se llama Magda: «Magdita viene de Tomatlán con su canasta de manzanas. Siempre, para toda la eternidad, será una mujer viajando con manzanas» ${ }^{44}$.

Es la presencia benéfica, «ríe su risa de manzana, se traga el mundo, comparte» ${ }^{45}$, les descubre... «la milpa, Tomatlán, Zacatlán, Apizaco, Puebla, las altas cañas, lustrosas varas mojadas»...46, la villa guadalupana... «nos enseña a la Morenita (...), nos cuenta de Juan Diego, es la primera vez que le rezamos a un indio ${ }^{47}$. Magda es el pueblo, un mundo desconocido de humildes sufridores que hacen posible la ociosa vida de los de arriba: «siempre se atiende a lo último. Para ella son los minutos más gastados»-observará la niña ${ }^{48}$. De hecho, el primer repunte social de Mariana parte de ahí, de la sintonía con quien ama: "¿por qué no soy yo la que lavo los platos? ¿Por qué no es mamá la que los lava?»49.

\section{UNA SOCIEDAD EXTRANJERIZADA: CIVILIZACIÓN/BARBARIE EN EL MÉXICO POSREVOLUCIONARIO}

La Flor de Lis se abre en Europa, en el seno de una familia cosmopolita y noble de duques descendientes de rusos y norteamericanos que ¡como no! viven en Paris. Nodriza, mademoiselle, comidas exquisitas, paseos por el Sena, vacaciones en La Baule, las tradiciones - «para nosotros lo principal son las buenas maneras» ${ }^{50}-$, los códigos lingüísticos, desde luego... todo ello contribuye a marcar ese nivel de la élite internacional que la familia de Mariana no abandonará en el Nuevo Mundo. Porque México vive la herencia del afrancesado XIX que culmina en Porfirio Díaz y sus construcciones de la Colonia Roma. "Éramos unas niñas desarraigadas, flotábamos en México» -dirá la narradora ${ }^{51}-$. 
$\mathrm{Y}$, es claro, «en mi casa saben más de Francia o Inglaterra que de México» ${ }^{52}$. En absoluto hay afán de aprender del país, si acaso asombro porque "aquí todo es desaforado» ${ }^{53}$, «la llanada es interminable; por donde quiera que uno voltee, la tierra se extiende cada vez más amplia, más perdediza» ${ }^{54}$-dirá Luz reescribiendo, aunque no de modo explícito, a Echeverría, el poeta de la primera generación romántica que sufrió el mismo impacto ante la inmensidad de la pampa a su vuelta de París-. El punto de referencia, el patrón que todo lo mide es el Viejo Mundo: «No, si esto no es Francia, aquí nada es de juguete» ${ }^{55}$. Pero «el mundo se adquiere en el otro continente» ${ }^{56}$ -dicen las visitas chismosas-. Lo cierto es que la élite no quiere saber nada del «mal gusto» posrevolucionario y extrañan las preguntas de Mariana: «Tu familia perdió todas sus haciendas, no veo por qué tanto interés» -le dirá un amigo de la abuela ${ }^{57}$-. Además «los políticos son los mismos ladrones que hicieron la Revolución. ¿Qué tuvo de bueno la revuelta esa de muertos de hambre? ${ }^{58}$.

Las buenas maneras desde la infancia cristalizan en el «tener clase» del mundo adulto, a años-luz de «la gente corriente, la gente del montón»-no del pueblo-. Por ello, la educación exclusiva en colegios norteamericanos donde confluyen las élites nacionales, la huida a las playas desiertas, el té y los vestidos europeos... «los jóvenes que se casan sólo entre sí por pura y llana discriminación, la insistencia en el francés como idioma separatista, ridículos, si lo aprendieron en México, o ¿acaso habían nacido en París?» ${ }^{9}$ - dirá Teufel a cuyo cargo están las mayores andanadas contra este grupo social-. Sin éxito alguno, ese grupo se afianza en lo suyo y recela de lo mexicano:

Los mexicanos no son constantes ni tenaces; no tienen voluntad de superación, van de trabajo en trabajo, son aprendices de todo, oficiales de nada; no tienen meta, trabajan solamente para subsistir, su cerebro subalimentado no da para más ${ }^{60}$.

Crítica muy dura, en boca de Berthelot, un empresario mexicano que se ha hecho a sí mismo desde abajo y pertenece a la élite de la Colonia Francesa, tan criticada por el estilo «marxista» de padre Teufel. Crítica que recoge la vieja herencia positivista de la inferioridad indígena, matizándola no obstante con factores contextuales como la subalimentación. «México es un inmenso jardín por cultivar. Lo único malo es la raza» ${ }^{61}$.

\section{IDENTIDAD FEMENINA/IDENTIDAD MEXICANA}

La niña Mariana siempre quiso gustar, caer bien incluso a las mademoiselles. En su nueva tierra se debatirá entre su natural anclaje junto a los suyos (familia y gens de connaissance -como dice la abuela-) y su deseo de «pertenecer». Por aquí entra en el texto el asunto de la identidad mexicana, tan traído y llevado en el ensayo y la novela del XX. La narración no deja de tener su ironía: «Al final de la guerra regresan todos aquellos que de chicos fueron mexicanos ${ }^{62}$... con el consiguiente rechazo de la gente vulgar:

Pinches refugiadas (...), cochinas extranjeras, regrésense a los Yunaites, lárguense a su país.

De azotea en azotea, entre las sábanas que chasquean resuena el grito y lo recibo como una bofetada. Qué vergüenza. Quisiera vender billetes de lotería en alguna esquina para pertenecer. O quesadillas de papa. Lo que sea ${ }^{63}$.

En un par de ocasiones, los diálogos del texto abordan el problema de fondo ¿cómo se adquiere la identidad? ¿Es un problema de genes, de sangre... o de voluntad? Para Mariana lo será por partida doble: la adolescencia le permitirá ver lo limitado de un mundo «muy antiguo» -le dirá su amiga judía y pintora-... Injusto y decadente -proclamará airado el padre Teufel-. Pero no hace falta esperar tanto, la mexicanidad le llegará desde dentro, a través de los de abajo -Magda- e incluso de la extravagante abuela, que la entrena a mirar el país, la tierra, la gente. Muy temprano, cuando es imposible que la decisión haya madurado, tal vez como mera reacción a los insultos -«güera, güerita»-, ya ha tomado partido:

- Pero tú no eres de México, ¿ৃverdad?

- Sí soy.

- Es que no pareces mexicana.

- Ah, sí, entonces ¿qué parezco?

- Gringa.

- Pues no soy gringa, soy mexicana.

- No se te ve.

- Soy mexicana porque mi madre es mexicana; si la nacionalidad de la madre se heredara como la del padre, sería mexicana.

- De todos modos, no eres de México.

- Soy de México porque quiero serlo, es mi país ${ }^{64}$.

El diálogo se repite, exactamente igual, en la página 139. El contexto es más dramático, la hora de buscar trabajo: «no vayas a decirles

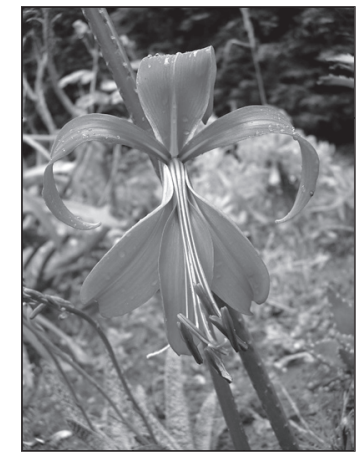

Flor de Lis.

52 Ibid., p. 49.

53 lbid., p. 37.

54 lbid.,p. 42. 55

Id.

56 lbid., p. 58.

57 lbid., p. 56. 58

Id. 59 Ibid., p. 285.

60 Ibid., p. 284.

61 Ibid., p. 132.

62 lbid., p. 89. 63 Id. 64 lbid., p. 88.
La Flor de Lis

MARÍA CABALLERO 


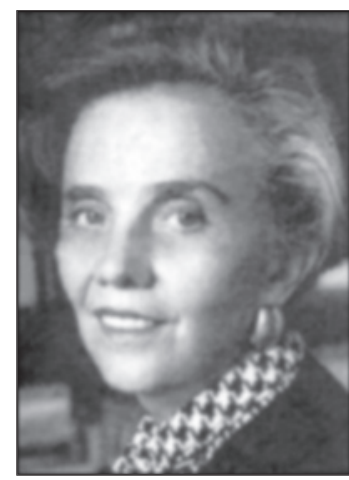

65

Ibid., p. 139

66

Ibid., p. 310.

67

Ibid., p. 324

68

Ibid., p. 104.

69

Ibid., pp. 19-20.

70

Ibid., p. 30. que no naciste mexicana porque ni caso te hacen». Estructuralmente y dentro del fragmentarismo que caracteriza esta autoficción, los dos pasajes marcan otros tantos momentos de incardinación posible: la llegada al país y el acceso al mundo laboral, a la adolescencia que quiere comprometerse: «si no eres de México, no tienes derecho a opinar» ${ }^{65}$.

Sea como fuere, Poniatowska parece haber secundado en su vida/escritura el consejo que el visionario Teufel deja a Mariana como testamento:... «atrévete a caminar en la multitud, entre los pelados, como ustedes los llaman, aviéntate, rompe el orden establecido» ${ }^{66}$. Por eso, la novela se cierra con estas palabras de la protagonista:

Me gusta sentarme al sol en medio de la gente, esa gente, en mi ciudad, en el centro de mi país, en el ombligo del mundo (...). Mi país es esta banca de piedra desde la cual miro el mediodía (...), mi país es la emoción violenta, mi país es el grito que ahogo al decir Luz, mi país es Luz, el amor de Luz. ; Cuidado!, es la tentación que reprimo de Luz, mi país es el tamal que ahora mismo voy a ir a traer a la calle de Huichapan número dos, a la FLOR DE LIS. De chile verde diré: Uno de chile verde con pollo67.

El utópico mestizaje: la flor de Lis, símbolo de la nobleza en Francia, emblema de los scouts, Francia en definitiva, ha encarnado en tierra mexicana, en el tamal hecho de maíz.

\section{MUJERES FLORES/FLORES DE PAPEL}

Las mujeres de la novela son, en definitiva, un manojo de flores... metáfora manoseada que la narradora consigue revitalizar en una refrescante viñeta metonímica en que la protagonista es Francis, si bien sintetiza una historia de generaciones:

flores, flores, flores, siempre flores que tía Francisca arregla a grandes manojos (...). Esas mujeres que van relevándose en cambiar el agua de las ánforas son mis antecesoras; son los mismos floreros que van heredándose de madre a hija (...). A diferencia de las flores de mi bisabuela, de mi abuela, de mi madre, mi tía, las mías serán de papel. Pero ¿en dónde van a florear? ${ }^{38}$.

La pregunta es una flecha directa al sentido y destino de la escritura femenina, detrás de la que se esconde Poniatowska. Es ya una autora reconocida, pero debe seguir indagando, abriendo nuevos caminos también como mujer. No sé hasta qué punto pudo elegir el formato de la edición, bonita en su sencillez, con pequeños motivos ideográficos que dan la pista temática al lector y sirven para estructurar en parágrafos lo que es un texto fragmentario, abierto, a modo de viñetas... y con dos grandes bloques temáticos: infancia europea-fijación materna/adolescencia-contexto cultural y religioso mexicano. Desde el punto de vista lingüístico, me parece más interesante la primera, cuajada de diminutivos cariñosos, reiteraciones y esquemas paralelísticos, comparaciones con animales... por ejemplo este sumario con que describe la primera educación de Mariana y Sofía, su hermana:

Durante siete años, día a día se ceban las perritas, engordan las cochinitas, se van trufando las gansitas, se les hacen hoyitos en los codos y en los cachetes, llantas en las piernas; tienen papada, sus pies son dos mullidos cojines para los alfileres; pesan tanto que sólo Nounou las aguanta. Tambaches de proteínas, de agua, de leche enriquecida, de grasa blanda como mantequilla civernesa, de crema espesa de vacas contentas, de jamón de Westphalia, petit-suisses, quesos crema, todo ello para que las dos muñecas de yema de huevo y de azúcar caramelizada se liberen de tanta bonanza, vaciándola sobre la alfombra de la Nursery ${ }^{69}$.

Tienen fuerza también las hipálages con que la narradora gusta de corporeizar lo intangible:

Nos besa y ya en la puerta entona: God bless you y en cada uno de los cinco rellanos repite: God bless you, children. Ruedan los god bless you escalera abajo en cascada de piedras redondas; los oímos hasta en el último escalón cuando su voz apenas perceptible nos bendice: God bless you ${ }^{70}$.

La segunda parte se complica y radicaliza con el tema religioso. Desde la referencia a los ejercicios espirituales que hace Mariana, el texto se llena de epígrafes en latín que alternan mayúsculas y minúsculas. He tratado, sin éxito, de vislumbrar su sentido -suponiendo que lo tenga-. Porque no existe un orden aparente en mi edición, las mayúsculas corresponden a las páginas 144-156, 161-172, 192, 204-214, 221-223, 347-252, 257-260, 264-268, 288-289, 295-299, 304 y 317-324. Las minúsculas cubren otras tantas: 157-160, 173-192, 195-204, 215-220, 243-246, 253-256, 261, 281, 293, 301 y 315. Su temática es religiosa, juega con las palabras del Angelus y culminan en una especie de exorcismo contra el diablo al que se opone la «sal de la sabiduría» (accipe sal 
sapientiae ${ }^{71}$. Una vía amarga, sin salida... Una religión así, tan malentendida, nunca podrá ser la respuesta que busca Mariana ${ }^{72}$.

A partir de un determinado momento ${ }^{73}$ se intercalan fragmentos del diario materno: llevada por la curiosidad y deseosa de compensar el desencanto ante el sacerdote, un iluminado que desbarra y pierde pie en sus propuestas, Mariana lo hojea y el texto lo incorpora estratégicamente como contrapunto que permite cerrar la narración volviendo a su punto de partida: la madre. El diario siempre va en cursivas (pp. 255, 271, 315...) y evidentemente duplica perspectivas sobre una historia que en la segunda mitad es más folletinesca que autobiográfica. Desde mi punto de vista, esta segunda parte contrabalancea el relato con cierto desequilibrio... Desequilibrio que las dos últimas páginas compensan retomando el leitmotiv de la narradora: el estéril destino de las mujeres, el miedo a la soledad, la esquizofrenia que desgarra a Mariana entre su formación elitista de cuño europeo y esa inclinación a mezclarse con la gente, único aporte positivo del controvertido padre Teufel.

Por último, un apunte sobre algo que me parece curioso: hay un momento, casi al final de la novela en que desaparece la primera persona. Son sólo un par de páginas de ¿̇autor en el texto, tal vez? Focalización externa, narrador omnisciente que focaliza a Mariana como parte de una estela de mujeres aureoladas por la soledad:

Basta cerrar los ojos para encontrar a Mariana en el fondo de la memoria, joven, inconsciente, candorosa. Su sola desazón, su pajareo conmueven; germina en su destanteo la semilla de su soledad futura, la misma que germinó en Luz, en Francis, en esas mujeres siempre extranjeras que dejan huellas apenas perceptibles (...), cuánta fragilidad Dios mío, qué se hace para retener criaturas así en la tierra si apenas son un poco de papel volando, apenas si se oye su susurro y eso, cuando hace mucho viento, schsssshehsss schssss schschssss ${ }^{74}$.

Mujeres ojerosas reflejadas en el espejo, que han conseguido diluir hasta sus hombres... Por aquí avanza y se abre paso otra interpretación, un mensaje nuevo en el texto: las mujeres de su familia no tocan tierra, son apenas un papel volandero que no deja huella. Mariana se rebela ante ese destino, quiere ser de carne y hueso como Sofía, que para lograrlo eligió... «asir la mano del hombre, cercar la realidad, pertenecer» ${ }^{75}$. ¿Lo conseguirá la rebelde Sofía?
UNA HISTORIA DEL YO: ¿AUTTOBIOGRAFÍA/AUTOFICCIÓN/NOVELA AUTOBIOGRÁFICA?

Tú tenías el afán de que el país te entrara por los ojos, abue...

-Sí-me responde- ahora te toca a ti memorizarlo ${ }^{76}$.

Quisiera poner mi cabeza en su hombro, doblarla contra su cuello, sentir su tibieza, preguntarle: Mamá ¿de qué hablarías en la mesa si te dejaran? ¿De tu ninez? ¿De tu padre muerto? ¿De tu relación con el padre Teufel? (...) Hoy como entonces, Luz dice frases que ruedan frágiles en el aire y caen sin ruido sobre la alfombra. Nadie las recoge, sólo yo, para que las sirvientas no las barran con el polvo de la mañana ${ }^{77}$.

Escritura como respuesta a una misión, explícitamente encomendada por la abuela, implícita en el deseo de rescatar y fijar para la posteridad a esa madre inasible, cuya intimidad misteriosa fascina a Mariana, la narradora. Y además, escritura como develación de una identidad al hilo de la trayectoria personal, ya que inventar el pasado permite al autor librarse de sus obsesiones ${ }^{78}$, y quizá vencer el miedo al tiempo que pasa. Una búsqueda que cuajará en determinados recursos estilísticos como exclamaciones, hipérboles, apóstrofes. Todo muy propio de las autobiografías que siempre tienen ese algo de plasmación de un yo desconocido incluso por el propio autor. No en vano es un yo textual, un yo otro, distinto... siempre de ficción incluso en diarios y escritos que alardean de sinceridad.

¿Autobiografía?/¿Autorretrato? Estrictamente ninguno de los dos, no se cumple el pacto referencial lejeuniano ${ }^{79}$, es «Mariana» y no «Elena Poniatowska» la protagonista. Aún así, ambos aspectos quedan recogidos en esta novela autobiográfica: de la autobiografía guarda el «hacer», es decir, la aspiración del escritor a conocerse en diacronía planteándose cómo y por qué ha llegado a ser quien es. Del autorretrato hereda la yuxtaposición, la estructura discontinua propia del «ser». Como diría Bellemin-Noël, la autobiografía nunca vale más que como ficción ${ }^{80}$, no es otra cosa que reorganizar la vida para transformarla en ficción. Lo importante es la coherencia interna de la obra, su aparente verosimilitud, y eso lo cumple. ¿Sinceridad? Es un valor desfasado... es famosa la feroz crítica de Valery en este sentido. De cualquier forma, es indudable que la elección de la primera persona determina la lectura.
El padre Teufel («diablo» en alemán) crea una expectación anormal en las jovencitas que en el caso de Mariana convive con posturas francamente blasfemas de la niña (p. 161, por ejemplo), más creíbles en la autora adulta.

73

Ibid., p. 234

74

Ibid., p. 321

75

Ibid., p. 322.

76

Ibid., p. 220.

77

Ibid., p. 224

78

... «c'est précisément ce réinvestissement du passé qui permet à l'auteur de se délivrer de faits anciens et obsédants, de les représenter et de les transformer en les revivant une fois encore», en Sébastien Hubier, Littératures intimes. Les expressions du moi, de l'autobiographie à l'autofiction, Paris, Armand Colin, 2005, p. 63. El autor sigue tratando este asunto en el siguiente epígrafe «vaincre enfin la peur du temps qui passe», pp. 72-74.

79

Aquí disiento de Pino-Ojeda quien pretende que el pacto se realiza, a pesar de la no coincidencia onomástica, debido a la «concomitancia» entre los hechos de la novela y la biografía de la autora.

80

Cf. Jean Bellemin-Noël, Biographies du désir, Paris, P.U.F., 1988.

La Flor de Lis

MARÍA CABALLERO 
81

Cf. S. Doubrovski, J. Lecarme et P. Lejeune, Autofictions et Cie, RITM, 1993.

82

"Celui qui dit je dans le livre est le je de l'écriture (...) c'est moi et ce n'est pas moi», en Roland Barthes, Le Grain de la voix, Paris, Seuil, 1981, p. 267.

83

Poniatowska, «La verdad más íntima», op. cit., p. 149.

84

Traduzco libremente las palabras de Hubier en el libro ya citado: «le je ne renvoie plus à une réalité permanente, mais au contraire à une multiplicité fragile qui ruine la croyance en une quelconque profondeur psychologique», p. 123.

85

Carmen Perilli. "Flores de abolengo: ficciones del yo en Elena Poniatowska», Primer Congreso Internacional CELEHIS de Literatura, Mar del Plata, 6-8 de diciembre 2001; en línea, http://www. freewebs.com/celehis/actas2001/H/Perilli.htm, p. 1.
La Flor de Lis podría corresponder a ese género tan de moda desde que Doubrovski ${ }^{81}$ lo definió en el 77: la autoficción. Género híbrido, ficcional y autorreferencial, que asume los códigos de la autobiografía relativizándolos. Un procedimiento seductor para reinventar la propia vida ${ }^{82}$; porque de hecho se inventa una personalidad y existencia -la de Mariana- pero conservando muchos rasgos de su identidad real -la de Elena Poniatowska-:

En esos dos libros, sobre todo en Lilus Kikus hay, al principio, elementos autobiográficos (...) Ciertas circunstancias de mi vida coinciden con algunas que forman parte de las historias narradas. Como le decía antes, creo que uno escribe siempre a partir de su realidad ${ }^{83}$.

¿Qué hay detrás, qué sentido tiene esta manipulación? Ese juego de voces y perspectivas narrativas responde al sentido no esencialista del yo propio de la posmodernidad. El yo no reenvía a una realidad permanente sino más bien a una multiplicidad frágil, que arruina la creencia en una profundidad psicológica ${ }^{84}$. El yo verdadero es el de la escritura y su credibilidad depende estrechamente del tono que utilice... ese yo es siempre un poco yo mismo, que lo actualiza al leerlo, que desea y experimenta por él.

Hay más aún: un escritor tiene su taller de laboratorio, los primeros escritos que funcionan como hipertexto de lo que vendrá después. La Flor de Lis tiene su sentido y especificidad, pero arranca de cuentos anteriores, publicados o inéditos, como han visto bien algunos críticos:

La Flor de Lis retoma relatos anteriores como «El convento» o «El inventario» (De noche viernes) que ficcionalizan linajes antiguos, densos en antigüedades; opresivos en atmósferas familiares. El texto se divide, de modo encubierto, en dos partes que producen un quiebre en la página 110: el relato de infancia dominado por el tono lúdico - «la escritura más fácil de su vida»-según la propia Poniatows$\mathrm{ka}$ - posee una unidad frente a la experiencia con el sacerdote Teufel originada en «El retiro", un relato independiente que se encontraba inédito ${ }^{85}$.

Incluso, si uno sigue husmeando descubre que «El retiro» es una historia retomada por la madre de la escritora, Paula Amor Poniatowska, en sus propias memorias, que la hija tradujo -no olvidemos que es francesa de origen mexicano- bajo el título No me olvides (1996). Un pequeño detalle de manejos intertextuales que demuestra las continuas interferencias entre vida y literatura. Y que aboga por la literariedad de La Flor de Lis. Un texto en el que la autora ha vertido su esquizofrenia cultural, compartiendo con el lector la angustia de encontrar su destino. 